\title{
Competencies of Apparatus and Internal Control System Effect on The quality of Financial Statement Information and Good Governance
}

\author{
Ibrahim Ahmad, Mahfudnurnajamuddin, Masdar Mas'ud, and Suriyanti
}

\begin{abstract}
The purpose of this study was to analyze the effect of the competencies of the apparatus and internal control systems on the quality of financial statement information and good governance. The study was conducted at the Makassar City Government. The population in this study was 44 Indonesian: Regional Working Unit (SKPD) in the Makassar City Government consisting of 687 people, and a sample of 268 respondents were obtained through the Slovin formula. Data from the questionnaire were analyzed using the Structural Equation Model using AMOS 18. The results found that the overall variables studied were apparatus competence and internal control systems both directly and indirectly had a positive and significant effect on the quality of financial statement information and good governance in the City Government Makassar. The dominant direct effect is the internal control system on the quality of financial statement information and good governance in the Makassar City Government. The dominant indirect effect is the internal control system through the quality of financial statement information on good governance in the Makassar City Government.
\end{abstract}

Index Terms - Competencies, good governance, internal control system, quality of financial statement information

\section{INTRODUCTION}

Assessing the quality of information on government financial statements is important and is needed to determine the use and utilization of budget allocations used by the government in carrying out development activities. Therefore, the government always carries out internal financial management to produce reliable quality financial information and makes it easy for the Indonesian Supreme Audit Board (BPK) to assess government financial management activities. The results of the examination of the Supreme Audit Board (BPK) on the Financial Statements of Local Governments (LKPD) throughout Indonesia showed that there are still many local governments that have not obtained a Fair Opinion without Exception (WTP) opinion. In the 2019 reporting year, the BPK recorded that only $58 \%$

Published on July 21, 2020

Ibrahim Ahmad, Indonesian Muslim University, Indonesia.

(corresponding e-mail: ibrahimahmad3112@gmail.com).

Mahfudnurnajamuddin, Indonesian Muslim University, Indonesia.

Masdar Mas'ud, Indonesian Muslim University, Indonesia.

Suriyanti, Indonesian Muslim University, Indonesia. or 312 LKPDs received WTP opinions. Meanwhile, other LKPDs were recorded as obtaining fair opinions with an exception (WDP) of 187 LKPDs, Not Expressing Opinion (TMP) of 30 LKPDs, and there were still 4 LKPDs that obtained unfair opinions (TW).

This illustrates the improvements achieved by local government entities in presenting a fair financial report in accordance with applicable principles. BPK's evaluation results show that LKPD who obtain WTP and WDP opinions generally have adequate internal control. The LKPD who obtained TW and TMP opinions requires improvements in internal control, as mandated in Act Number 17 of 2003 concerning State Finances, where the Regional Government is obliged to implement accrual-based accounting in the presentation of full financial statements. Accrual-based financial statements are intended to provide better benefits for stakeholders.

BPK Audit Results for Makassar City Government to realize the implementation of accrual-based Government Accounting Standards (SAP) that still have several problems including: (1) regulatory and policy related to the implementation of accrual-based SAP has not been fully implemented properly, (2) analysis of HR needs financial, asset and information technology managers and inspectorates as LKPD reviewers are inadequate, according to their competencies, and (3) in terms of technology management, the city government has not conducted an accrual-based application system analysis, and local governments have not made plans and conducted periodic evaluations of the system the application is in improving the quality of financial statement information and realizing good governance in the government. Based on the phenomenon of the application of good governance produced by local governments is influenced by the competence of the apparatus, internal control systems and the quality of financial statement information.

The application of good governance, influenced by the competence of the financial apparatus, the internal control system and the quality of financial statement information in carrying out various activities related to the preparation, reporting, evaluation and evaluation of financial management activities [1]. Considering the importance of financial management, it is necessary to have a substantive understanding in looking at issues related to financial management to examine in detail the influence of competencies of the financial management apparatus and the application of internal control systems to the quality of financial statement information in order to realize the good 
governance of the Makassar City Government.

Phenomenon that needs to be observed in the past five years (2015-2019), the results of the Makassar City Government's financial reports that have not provided quality financial statement information, in this case the financial statements that reach the target despite the expected BPK WTP assessment above realization 90\% Government financial reports that are reported annually from 2015 to 2019 are based on the results of the financial statement assessment of each Regional Work Unit (SKPD) with measurements that refer to Government Regulation Number 71 of 2010 concerning Government Accounting Standards as a reference in assessing quality financial statement information that is understandable, reliable, relevant, timely, consistent and comparable. LKPD is a form of local government accountability report to public demands for regional financial management for one fiscal year. In preparing financial reports, local governments must follow the Government Accounting Standards (SAP) regulated in Government Regulation No. 71 of 2010.

The purpose of this is to make it more accountable and the more necessary quality of financial statement information. The realization of the financial performance of the Makassar City Government has experienced ups and downs. In 2015 the percentage of realization of financial statements with a percentage of $85.54 \%$ decreased in 2016 to $83.19 \%$, then increased in 2017 to $86.46 \%$ and in 2018 amounted to $87.82 \%$, and in 2019 the realization of financial statements showed a percentage of $86.39 \%$. Overall, it has not yet reached the $90 \%$ realization to be assessed as a PAP, so the assessment of the quality of information on the financial statements of the Makassar City Government is WDP.

The description above shows the gap or gap about the quality of financial statement information that is still WDP, it is necessary to apply the theory of accountability or accountability theory proposed by Gordon (2018: 66) that accountability is the core in improving the quality of information from financial reporting by improving the quality characteristics of information financial statements to be easily understood, reliable, relevant, timely, consistent and comparable. This has become a reference standard for assessing the quality of government financial statement information in accordance with Government Regulation No. 71 of 2010. For this reason, support is needed from the application of good governance in the management of government financial statements.

The low quality of information on financial statements of the organization in the Makassar City Government in relation to the implementation of the assessment of good governance has not shown supporting synergy in realizing good governance.

The facts show that due to the quality of financial statement information that is in line with the expected target, it still cannot realize good governance. As it is known that the quality of financial statement information is still poorly understood, not yet reliable in preparation, not yet relevant, not timely, and not yet consistent and cannot be compared in any financial information provided by the government to the public. Based on this description it becomes a fact that due governance to the lack of good organizational, causing officers who are executing in the financial sector are not ready to carry out the main tasks and functions to improve the quality of financial statement information. For this phenomenon, it is necessary to apply the principle of good governance as a theory gap used to overcome the problem of gap research about good governance in the Makassar City Government.

Governance principle theory [2] good governance is organizational built on the basis of 9 (nine) principles to achieve goals. The nine principles are participation, law enforcement, transparency, responsibility, and consensus, equality of rights, effectiveness, efficiency and accountability. However, in the assessment of good governance in the Makassar City Government are assessed based on transparency, participation, accountability and coordination. Good governance implemented by Makassar City Government should be based on the actualization of the principles of good governance of good governance or good governance of healthy organizations to improve the quality of government financial statement information.

Paying close attention to financial problems in the Makassar City Government where good governance from each SKPD does not support the realization of improving the quality of financial statement information. This has become a phenomenon that needs to be addressed. Empirically the cause of the quality of financial statement information and good governance of the organization is low, this is influenced by the low actualization of work of executors in the financial sector who are still less competent as an executing apparatus that needs to be improved and are still unable to implement a good internal control system to improve the quality of financial statement information and realize good governance government. Improving the quality of financial statement information and realizing good governance and influenced by the competence of the apparatus in this case the professionalism of financial statement managers in carrying out tasks in the financial sector.

Empirically, in reality there are still those who are less financially competent in carrying out and developing the assigned tasks. Their competence is still not able to answer various problems in the financial sector, has not made important transformations in developing good governance and the quality of financial statement information, so that there are often delays, mistakes and mismatches in various regulations, as well as the leadership's policy in carrying out financial sector tasks assigned. Due to the low competency of the financial apparatus executives in the Makassar City Government, it becomes a gap research that needs to be given a solution in addressing the importance of managerial competencies that are addressed in influencing the quality of financial statement information and good governance.

Gap theory that can be used in this case is the ability oriented theory [3] the professionalism manifested from the ability orientation called competence. There are three elements of the so-called KSA who build competence i.e. knowledge, skills and attitude.

This is in accordance with the competency appraisal of the apparatus based on Indonesian Government Regulation Number 101 of 2000 concerning the Education and Training of Civil Servants, which explains the competency of the 
apparatus based on knowledge, skills and attitudes.

It is realized that the success of a government organization in managing regional finances in this case the Makassar City Government organization is inseparable from the influence of the internal control system which gives effect in carrying out good governance and improving the quality of financial statement information. One that needs to be considered in conducting good governance and the quality of financial statement information is the importance of the influence of the internal control system on the implementation of financial reporting activities in an organization.

The Makassar City Government's internal control system has not yet demonstrated an integrated control system in developing financial tasks. Found in various daily activities of several SKPDs have not been able to carry out an environmental control system in the form of controlling all activities of the financial activities of agencies, there are still many financial activities that cannot be controlled for assessing the financial risks posed, are still low in controlling financial activities, providing control of information and communication that is rarely carried out and the low level of financial monitoring activities on various programs and activities that can be reported properly.

As a result of internal control systems in several SKPD Makassar City Government has less influence in improving the quality of financial statement information and realizing good governance. Overcoming the gap research relating to internal control systems as affecting the quality of financial statement information and good governance, it is necessary to apply the theory of controlling activities or activity controlling theory proposed [4] assessing financial activities can be controlled through a control system environment, risk assessment, information communication and monitoring activities. This is in accordance with Indonesian Government Regulation No. 60 of 2008 concerning the Government Internal Control System, where the control of these activities is important internally to support the realization of good governance and the quality of government financial statement information / The following shows the gap or gap research about the influence of apparatus and system competencies internal control over the quality of financial statement information and good governance, in the form of research results from previous studies.

The results of empirically research that show the influence of apparatus competence on the quality of financial statement information [5,6,7,8,9]. The results of others research that show the influence of the internal control system on the quality of financial statement information $[5,6,7,9,10,11]$. The results of research that show the influence of apparatus competence on good governance $[12,13,14,15]$. The results of research that show the influence of the internal control system on good governance $[5,8,9,12]$. The results of research that show the influence of the quality of financial statement information on good governance $[5,8,9,12,13,14]$. Based on the disclosure of factual phenomena, data, theoretical gaps and relevant observational gaps as well as previous studies above, researchers are interested in researching by selecting the title: Effect of Apparatus Competence and Internal Control Systems on Information Quality of Financial Statements and Good Governance of Makassar City Government.

\section{PROCEDURE FOR PAPER SUBMISSION}

\section{A. Competencies of apparatus}

Ability orientation theory [3] the professionalism is manifested from the ability orientation called competence. There are three elements of competency assessment commonly referred to as KSA, namely knowledge, skills and attitude. This is in accordance with the competency appraisal of the apparatus based on Indonesia, Government Regulation Number 101 of 2000 concerning the Education and Training of Civil Servants, which explains the competency of the apparatus based on knowledge, skills and attitudes.

$\mathrm{H}_{1}$ : Competence of apparatus has a positive effect on the quality of financial statement information

$\mathrm{H}_{3}$ : Competence of apparatus has a positive effect on good governance

$\mathrm{H}_{6}$ : Competence of apparatus through the quality of financial statement information has a positive effect on good governance

\section{B. Internal Control Systems}

Controlling activity theory [4] that assessing the quality of financial statements can be controlled through an environmental control system, risk assessment, information communication and monitoring activities. Control of these activities is important internally to support the realization of good governance and the quality of financial statement information, which also refers to Government Regulation Number 60 Year 2008 concerning Government Internal Control Systems.

$\mathrm{H}_{2}$ : Internal control system has a positive effect on the quality of financial information.

$\mathrm{H}_{4}$ : Internal control system has a positive effect on good governance

$\mathrm{H}_{7}$ : The apparatus internal control system through the quality of financial statement information has a positive effect on the good governance

\section{The quality of financial statement information}

The relevant theory used is the accountability theory [1] that accountability is the core in improving the quality of financial statement information by making improvements to the quality characteristics of financial statement information so that it is easy to understand, reliable, relevant, timely, consistent and comparable. Good Governance The governance principle theory [2] the good governance is built on the basis of nine principles to achieve goals. Referring to this, the assessment of good governance in the Makassar City Government is only assessed based on transparency, participation, accountability and coordination.

$\mathrm{H}_{5}$ : The the quality of financial statement information has a positive effect on the good governance 


\section{METHODOLOGY}

This research is designed to answer the problems that have been formulated and the objectives to be achieved and test the hypothesis. The location of the study was conducted at the Makassar City Government as the object of research for the influence of apparatus competence and internal control systems on good governance and the quality of government financial statement information. Research time is scheduled for three months from January to March 2020. There are two types of research, namely quantitative and qualitative research. Sources of data in this study consisted of primary and secondary data. Data collection techniques (instruments) used was observation, questionnaire, interview and documentation. The population in this study was 44 SKPDs in the Makassar City Government consisting of 687 people, and a sample of 268 respondents was obtained through the Slovin formula. Data from the questionnaire were analyzed using the Structural Equation Model using AMOS 18 assistance

\section{RESEARCH FINDINGS}

The theoretical model that has been built on the hypothesis will be illustrated in a flowchart. The path diagram will make it easier for researchers to see the causality relationships to be tested. Estimation analysis is done by analyzing the full-model to see the suitability of the model and the causality relationships built in the model being tested. The full model is done by replacing two arrows of correlation with one arrow symbolizing the hypothesis given in this study. Here are the results of the full model estimation in this study:

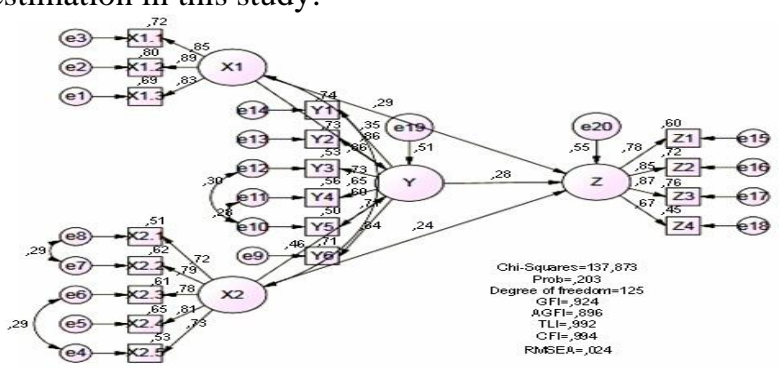

Fig. 1. AMOS Results

Testing the suitability of the model is evaluated through a review of various criteria goodness of fit. For this reason, the first step taken is to evaluate whether the data used can meet the assumptions needed in SEM analysis. If this assumption has been fulfilled, then the model can be tested. Chi-Square value is 137.873 with a probability value of 0.203 ( $p>0.05$ ), including good category (FIT). GFI value of 0.924 is more than 0.90 included in both categories (good fit), then the value of CMIN / df of 1,103 was under 2 included in both categories (goodness of fit), a value of 0.024 RMSEA below 0.08 are included in the category good (good fit), the AGFI value of 0.896 is below the recommended value of 0.90 included in the category of good enough (marginal) [16].

Furthermore, the TLI value of 0.992 , CFI of 0.994 above 0.90 is included in both categories. According to Hair et al., (2013) suggested that none of the measures of goodness of fit indices (GFI) can be used exclusively as a basis for evaluating the suitability of the whole model [17]. Thus it can be stated that from the results of this test, the model can be used. This means that empirically the influence of the competence of parents' apparatus and internal control systems with independent learning strategies with the quality of government financial statement information as a mediator variable is fit with the theoretical model. Based on the empirical model proposed in this study, testing of hypotheses can be tested through path coefficient testing on structural equation models. Hypothesis testing by looking at the value of $p$ value, if the value of $p$ value is less than 0.05 then the relationship between variables is significant. It also explains the direct effect means that there is a positive influence. The test results are presented in the following table:

TABLE I: DIRECT

\begin{tabular}{llc}
\hline \hline \multicolumn{1}{c}{ Exogenous } & \multicolumn{1}{c}{ Endogenous } & Prob. \\
\hline Apparatus competence & $\begin{array}{l}\text { Quality of government } \\
\text { financial statement } \\
\text { information } \\
\text { Quality of government } \\
\text { Internal control systems }\end{array}$ & 0.000 \\
& $\begin{array}{l}\text { information } \\
\text { Apparatus competence }\end{array}$ & 0.000 \\
$\begin{array}{l}\text { Internal control systems } \\
\text { Quality of government } \\
\begin{array}{l}\text { financial statement } \\
\text { information }\end{array}\end{array}$ & Good governance & 0.003 \\
\hline \hline
\end{tabular}

The indirect effect means that there is a positive influence indirectly between the variables, and the total effect that is the accumulation of direct effects and indirectly

TABLE II: INDIRECT

\begin{tabular}{llll}
\hline \hline \multicolumn{1}{c}{ Exogenous } & \multicolumn{1}{c}{ Intervening } & Endogenous & Prob. \\
\hline $\begin{array}{l}\text { Apparatus } \\
\text { competence }\end{array}$ & $\begin{array}{l}\text { Quality } \\
\text { government } \\
\text { financial } \\
\text { statement } \\
\text { Internal control } \\
\text { systems }\end{array}$ & Good governance & \\
& information & & 0.036 \\
& & & 0.027 \\
\hline
\end{tabular}

Hypothesis 1 Effect of apparatus competence on information quality of government financial statements based on a coefficient value of 0.349 with a value of $\mathrm{p}=0.000<0.05$. Thus it can be concluded that the competency of the apparatus has a significant effect on the quality of government financial statement information.

Hypothesis 2 The influence of the internal control system on the quality of information on government financial statements based on the coefficient value of 0.462 with a value of $p=0.000<0.05$. Thus it can be concluded that the internal control system has a significant effect on the quality of government financial statement information. 
Hypothesis 3 The effect of apparatus competence on good governance is based on a coefficient value of 0.289 with a value of $\mathrm{p}=0.003<0.05$. Thus it means that the competence of the apparatus has a significant effect on good governance.

Hypothesis 4 The influence of the internal control system on good governance based on a coefficient value of 0.243 with a value of $\mathrm{p}=0.026<0.05$. Thus it means that the internal control system has a significant effect on good governance.

Hypothesis 5 The influence of information quality on government financial statements on good governance based on a coefficient value of 0.276 with a value of $\mathrm{p}=0.010<0.05$. Thus it means that the quality of information on government financial statements has a significant effect on good governance.

One of the weaknesses of AMOS 23 compared to other SEM programs as it lies in the insignificance of the indirect effect. Before determining the conclusion of accepting a hypothesis first, we need testing indirect with the help of Sobel Test Analysis, in this study the researchers used an online calculator with the outputs following:

\begin{tabular}{|c|c|c|c|c|c|}
\hline & Memasukkan: & & Statistik uji: & Std. Kesalahan: & p-nilai: \\
\hline Sebuah & 0.280 & Tes tangis: & 2.09148005 & 0.05167632 & 0.03648505 \\
\hline$b$ & 0.386 & Tes Aroian: & 2.03924569 & 0.05299999 & 0.04142551 \\
\hline${ }^{S}$ & 0.079 & Tes Goodman: & 2.14794552 & 0.05031785 & 0.03171808 \\
\hline$s_{b}$ & 0.149 & Reset all & \multicolumn{3}{|c|}{ Menghitung } \\
\hline
\end{tabular}

Fig. 2. $\mathrm{H}_{6}$ Sobel test

Hypothesis 6 Apparatus competence on good governance with variable quality of government financial statement information as a mediating variable. The results of the indirect effect test on the Sobel Test with p-value testing both sobel (0.036), Aroian (0.041), Goodman Test $(0.031)$ are all less than the value of $\alpha=5 \%(0.0 \%)$. Based on the three tests the results of the indirect effect test of the apparatus competency have a significant effect on good governance through the quality of government financial statement information on hypothesis 6 accepted

\begin{tabular}{|c|c|c|c|c|c|}
\hline & Memasukkan: & & Statistik uji: & Std. Kesalahan: & p-nilai: \\
\hline Sebuah & 0.398 & Tes tangis: & 2.2161844 & 0.06932095 & 0.02667888 \\
\hline$b$ & 0.386 & Tes Aroian: & 2.17319093 & 0.07069236 & 0.02976595 \\
\hline$s_{\mathrm{a}}$ & 0.093 & Tes Goodman: & 2.26183488 & 0.06792185 & 0.02370761 \\
\hline$s_{b}$ & 0.149 & Reset all & & Menghitung & \\
\hline
\end{tabular}

Fig.3. $\mathrm{H}_{7}$ Sobel test

Hypothesis 7 The effect of internal control systems on good governance with the variable quality of government financial statement information as mediation. The test of results indirect effect on the Sobel Test with p-values testing both sobel (0.027), Aroian (0.030), Goodman Test (0.024) all three are less than the value of $\alpha=5 \%$ (0.05). Based on the three tests the test results of indirect effect the internal control system have a significant effect on good governance through the quality of government financial statement information on hypothesis 7 accepted.

Analysis of direct effects, indirect effects, and total effects between variables in the model, is used to compare the effect of each variable construct. The direct effect is the coefficient of all coefficient lines with one end of the arrow, while the indirect effect is the effect that appears through an intervening variable while the total effect is the effect of various relationships.

Based on the results of the study found that there are three findings that are incompatible with the proposed hypothesis, namely: (1) overall the variables studied are apparatus competence and internal control systems both directly and indirectly have a positive and significant effect on the quality of financial statement information and good governance in the City Government Makassar; (2) the dominant direct effect, namely the internal control system on the quality of financial statement information and good governance in the Makassar City Government; and (3) indirect effect the dominant, namely the internal control system through the quality of financial statement information on good governance in the Makassar City Government.

\section{CONCLUSION}

Based on the analysis of the results and discussion of the study, it was concluded as follows: (1) the competence of the apparatus has a positive and significant effect on the quality of the financial information of the Makassar City Government. In general, the apparatus in each SKPD work unit has been competent in the field of finance in preparing financial reports to provide financial statement information to the public; (2) the internal control system has a positive and significant effect on the quality of information on the Makassar City Government's financial statements. The internal control system that is implemented is appropriate in producing quality financial statement information; (3) Apparatus competence has a positive and significant effect on good governance in the Makassar City Government. This means that the apparatus already understands their field of work and is able to make financial reports by applying the principles of financial statement preparation;

(4) Internal control systems have a positive and significant effect on good governance in the Makassar City Government. The internal control system that is implemented is in accordance with the principles of management in preparing financial statements of the 
government; (5) the quality of financial statement information has a positive and significant effect on good governance in the Makassar City Government. The actualization of the presentation of quality financial statement information has been implemented well in realizing good governance in the financial sector; (6) apparatus competence through the quality of financial statement information has a positive and significant effect on good governance in the Makassar City Government. The competence of the apparatus in preparing quality financial reports contributes to good governance in the financial sector; and (7) the internal control system through the quality of financial statement information has a positive and significant effect on good governance in the Makassar City Government. The internal control system that is implemented is appropriate in the preparation of quality financial reports in an effort to realize good governance in the financial sector.

\section{REFERENCES}

[1] Parkhurst, J. (2017). The politics of evidence: from evidence-based policy to the good governance of evidence. Taylor \& Francis. pp. 182185 .

[2] Arthur, Warshind, (2018). Corporate Auditing and Management. Blackwell Publishing, New York. pp. 185-192

[3] Spencer, L. M., and Spencer, P. S. M. (2016). The Principle of Good Governance. John Wiley \& Sons. Application. McGraw Hill International Edition, New York. pp. 73-79

[4] Boynton, John, and Johnson, Mc, (2018). Internal Auditing Report: Management and Application. McGraw Hill International Edition, New York. pp. 319-321,

[5] Nurlis and Winqin Yadiati, (2017). The Influence of Internal Control Effectiveness, Information Technology Utilization and Human Resources Competence on Local Government Financial Reporting Quality. Research Journal of Finance and Accounting. 8(12) pp. 119127 ,

[6] Mulyo Agung and Srihadi Winarningsih, (2017). Effect of Auditor and Internal Control Competence Apparatus for Local Government Quality of Financial Reporting. European Journal of Accounting, Auditing and Finance Research 4(7). pp. 113-127.

[7] Putra, B. D., and Amar, S. (2015). Pengaruh Kompetensi Sumber Daya Manusia, Penerapan Sistem Pengendalian Intern Pemerintah, dan Penerapan Standar Akuntansi Pemerintah Terhadap Kualitas Laporan Keuangan Pemerintah Kota Padang. Jurnal Riset Manajemen Bisnis dan Publik, 3(1) pp. 1-24

[8] Rusvianto, D., Mulyani, S., and Yuliafitri, I. (2018). Pengaruh Pelaksanaan Sistem Pengendalian Internal Pemerintah dan Kompetensi Sumber Daya Manusia terhadap Kualitas Laporan Keuangan Pemerintah Daerah (Studi Empiris pada SKPD Kota Bandung). Banque Syar'i: Jurnal llmiah Perbankan Syariah, 4(1). pp.33-67.

[9] Haryono Umar, Sidin Usman and Rahima Br. Purba, (2018). The Influence of Internal Control and Competence of Human Resources on Village Fund Management and the Implication on the Quality of Village Financial Reports. International Journal of Civil Engineering and Technology (IJCIET) 9(7).pp. 1523-1531,

[10] Napitupulu, I. H., Situngkir, A., Basuki, F. H., and Nugroho, W. (2020). Optimizing good Corporate Governance Mechanism to Improve Performance: Case in Indonesia's Manufacturing Companies. Global Business Review, 0972150920919875.

[11] Ayagre, P., Appiah-Gyamerah, I., and Nartey, J. (2014). The effectiveness of Internal Control Systems of banks. The case of Ghanaian banks. International Journal of Accounting and Financial Reporting, 4(2), pp.377-385.

[12] Afiah, N. N., and Rahmatika, D. N. (2014). Factors influencing the quality of financial reporting and its implications on good government governance. International Journal of Business, Economics and Law, 5(1).pp.111-121.

[13] Irvan, N., Mus, A. R., Su'un, M., and Sufri, M. (2017). Effect of Human Resource Competencies. Information Technology and Internal Control Systems on Good Governance and Local Government
Financial Management Performance. IRA-International Journal of Management \& Social Sciences, 8(31-45), 2455-2267.

[14] Gamayuni, R. R., and Hendrawaty, E. (2020). E-Planning, EBudgeting and the Quality of Government Institution Performance Accountability System in Indonesia. Journal of Talent Development and Excellence.pp. 218-225.

[15] Hasanuddin, R., and Sjahruddin, H. (2017). The structure of emotional intelligence, spiritual intelligence and its relationship with work enthusiasm and auditor performance. Structure, 3(1).pp.67-85

[16] Toban, C., and Sjahruddin, H. (2016). The antecedent and consequence of Organizational Commitment and Job Satisfaction. Journal of Business and Management Sciences, 4(2). pp.26-33.

[17] Hair, J. F., Ringle, C. M., and Sarstedt, M. (2011). PLS-SEM: Indeed a silver bullet. Journal of Marketing theory and Practice, 19(2). pp.139-152. 